RESEARCH PAPER RP1527

Part of Journal of Research of the National Bureau of Standards, Volume 30, March 1943

\title{
PERFORATED COVER PLATES FOR STEEL COLUMNS: COMPRESSIVE PROPERTIES OF PLATES HAVING CIR- CULAR PERFORATIONS AND A WIDTH-TO-THICKNESS RATIO OF 53
}

\section{By Ambrose H. Stang and Martin Greenspan}

\section{ABSTRACT}

Tests were made to determine the mechanical properties of perforated cover plates intended to be used as a substitute for lattice bars or batten plates in built-up box-type columns. Each test column was built up from one perforated plate and either two or four angles. Columns with unperforated plates were used as controls.

This paper gives the results of the tests on columns having plates of three different perforation spacings.

It was found that the perforated plates contributed to the strength and to the stiffness of the columns, and that the factor of stress concentration, due to the presence of the perforations, varied from 2.5 to 3.4 based on the gross area $(2.2$ to 2.8 based on the net area).

\section{CONTENTS}

I. Introduction

II. Cover-plate columns _...

1. General

2. Dimensions _......... 178

3. Condition of ends 180

III. Procedure

1. Coupons $\ldots \ldots$

2. Columns

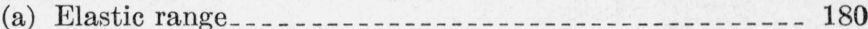

(b) Maximum load

IV. Results _...

1. Coupons

2. Columns _....... 181

(a) Modulus of column and effective area of plate . ..... 181

(b) Stresses_....... 182

(1) On the edge of the perforation $\ldots \ldots \ldots \ldots 2$

(2) On the surfaces of the plate

(c) Maximum-load test_........................ 199

(1) Stress-strain graphs

(2) Deflections

(3) Maximum load and effective area of plate.... 199

V. Summary

1. Modulus

2. Stress distribution

3. Strength $\ldots \ldots \ldots$

VI. References 


\section{INTRODUCTION}

This paper is the fifth of a series dealing with the mechanical properties of perforated cover plates intended to be used as a substitute for lattice bars or batten plates in built-up box-type columns. An outline of the program, and results for plates having ovaloid perforations and widths of 15,20 , and 25.5 inches have been given in previous Research Papers $[1,2,3,4] .^{1}$

In this paper are presented the test results for the $C 1$ series of plates. These plates were $20 \mathrm{in}$. wide by $3 / 8$ in. thick, thus having a width-to-thickness ratio of 53. The perforated plates of this series had circular perforations 9 in. in diameter. The net-to-gross crosssectional-area ratio was 0.55 .

\section{COVER-PLATE COLUMNS}

\section{GENERAL}

The details of the $C 1$ plates and of the angles are shown in figure 1 . The perforated $C 1$ plates were all of the same nominal dimensions as to length, width, thickness, and number and diameter of perforations but differed with regard to perforation spacing (i.e., the distance between centers of adjacent perforations). The perforation spacing was 21 inches for the $C 1 A$ plates, 33 inches for the $C 1 B$ plates, and 45 inches for the $C 1 C$ plates. The $C 1 D$ plates had the same nominal dimensions as the perforated $C 1$ plates but had no perforations. The $C 1 D$ plates shown in figure 1 are the same plates as the $C B D$ plates, the compressive properties of which are given in reference [4].

Each plate shown in figure 1 represents three like plates, designated $(0-1),(2-3)$, and $(4-5)$, and the angle shown represents many like angles which were used interchangeably with the plates to form the columns of which the cross sections are shown in the figure. The angles used with the plates to form the columns are given in table 1.

TABLE 1.-Angles used for the C1 columns

\begin{tabular}{|c|c|}
\hline Column designation 1 & Angle designations \\
\hline 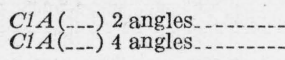 & $\begin{array}{l}C 5 D(4-5), C 5 G(0-1) . \\
C 5 D(4-5), C 5 G(0-1), C 5 B(4-5), C 5 G(2-3) .\end{array}$ \\
\hline $\begin{array}{l}C 1 B(--) \\
C 1 B(--) \\
C\end{array}$ angles & $\begin{array}{l}C 5 B(4-5), C 5 G(2-3) . \\
C 5 B(4-5), C 5 G(2-3), C 5 D(4-5), C 5 G(0-1) .\end{array}$ \\
\hline $\begin{array}{l}C 1 C(-\ldots) 2 \text { angles... } \\
C 1 C(--) \\
4 \text { angles... }\end{array}$ & $\begin{array}{l}C 5 H(0-1), C 5 H(2-3) . \\
C 5 H(0-1), C 5 H(2-3), C 5 D(4-5), C 5 G(0-1) .\end{array}$ \\
\hline $\begin{array}{l}C 1 D(-\ldots) 2 \text { angles } \\
C 1 D(-. . .\end{array}$ & $\begin{array}{l}C 5 A(0-1), C 5 E(4-5) . \\
C 5 A(0-1), C 5 E(4-5), C 5 A(2-3), C 5 E(0-1) .\end{array}$ \\
\hline
\end{tabular}

1 The 3 columns represented by each of the above designations contained the same angles.

\section{DIMENSIONS}

The dimensions given in figure 1 are nominal. There were the usual commercial variations in the thicknesses and widths of the plates and angles. The variations in the dimensions of the perforations were considerably greater; for some plates the difference between the

\footnotetext{
1 Figures in brackets indicate the literature references at the end of this paper.
} 


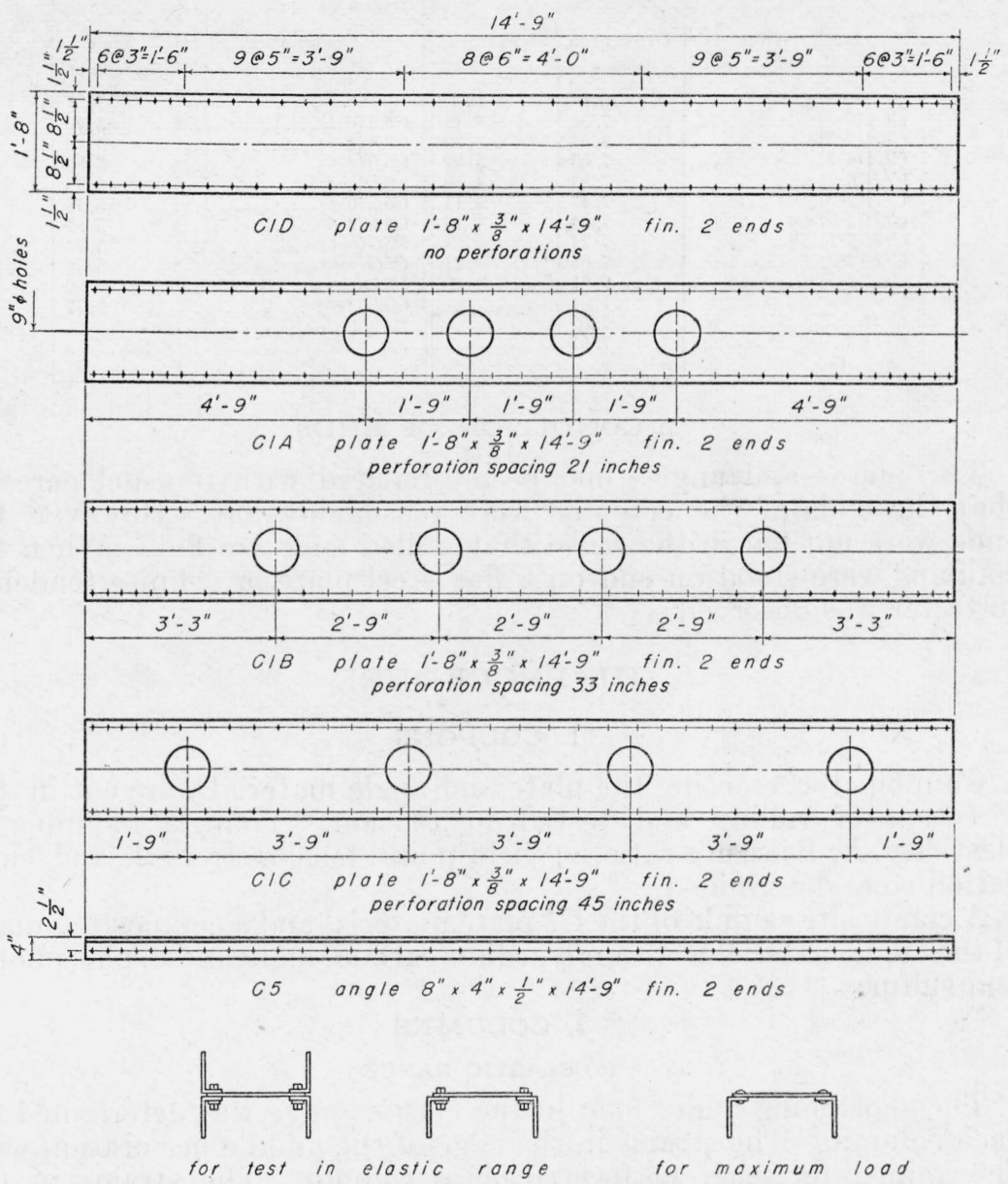

Figure 1.-Plates and angles for the C1 columns 
minimum and maximum perforation diameter (width) was of the order of $0.3 \mathrm{in}$. The cross-sectional areas of the plates and angles, computed from the measured dimensions, are given in table 2 .

TABLE 2.-Cross-sectional areas of plates and angles for the C1 columns

\begin{tabular}{|c|c|c|c|c|}
\hline \multicolumn{2}{|c|}{ Plates } & \multirow[b]{2}{*}{ Net area } & \multicolumn{2}{|l|}{ Angles } \\
\hline Designation & Gross area & & Designation & Area \\
\hline & in..$^{2}$ & $i n .{ }^{2}$ & & in..$^{2}$ \\
\hline $\begin{array}{l}C 1 A(0-1) \\
C 1 A(2-3)\end{array}$ & $\begin{array}{l}\text { 7. } 54 \\
7.54\end{array}$ & $\begin{array}{l}4.12 \\
4.20\end{array}$ & $\begin{array}{l}C 5 A(0-1) \ldots \\
C 5 A(2-3)\end{array}$ & $\begin{array}{l}5.79 \\
5.78\end{array}$ \\
\hline C1A $(4-5)$ & 7.63 & $\begin{array}{l}4.22 \\
4.20\end{array}$ & $C 5 B(4-5) \ldots$ & 5.80 \\
\hline$C 1 B(0-1)$ & 7. 53 & 4.16 & $C 5 D\left(4^{-5}\right) \ldots$ & 5. 79 \\
\hline$C 1 B(2-3)$ & 7.47 & 4.14 & $C 5 E(0-1)$ & 5. 78 \\
\hline C1R $(4-5)$ & 7.54 & 4.18 & $C 5 E\left(4^{-5}\right)=$ & 5.81 \\
\hline C1C $(0-1)$ & 7. 74 & 4.28 & $C 5 G(0-1) \ldots$ & 5.74 \\
\hline C1C $(2-3)$ & 7.65 & 4.21 & $C 5 G(2-3)_{--}$ & 5.78 \\
\hline C1 $C\left(4^{-5}\right)$ & 7.61 & 4.20 & $C 5 H(0-1) \ldots \ldots$ & 5.80 \\
\hline$C 1 D(0-1)$ & 7.67 & $-\infty$ & $C 5 H(2-3)$ & 5.77 \\
\hline$C 1 D(2-3)$ & 7.62 & -....- & & \\
\hline$C 1 D(4-5)$ & 7.57 & & & ....... \\
\hline
\end{tabular}

\section{CONDITION OF ENDS}

The plates and angles had been prepared with unusual care, so that the ends of the columns were reasonably flat. However, the ends were not flat in the sense that milled ends are flat. When the columns were stood on end on a flat steel plate, a definite tendency to teeter was observed.

\section{PROCEDURE}

\section{COUPONS}

Coupons representing the plate and angle material were cut in the direction of rolling and tested in tension. Young's modulus of elasticity, $E$; Poisson's ratio, $\nu$; yield point, tensile strength, and elongation were determined.

A composite sample of the $C 1$ plate material and a composite sample of the angle material were analyzed for carbon, manganese, phosphorus and sulfur:

\section{COLUMNS}

\section{(a) ELASTIC RANGE}

The shortening under load in the elastic range was determined for each column. The strains in the edge of the middle perforation were determined for each perforated-plate column. The strains in the surfaces of the plate were determined for the middle bay of one of each group of three like perforated-plate columns having four angles. The distribution of stress in the middle bay of each of these columns was calculated from the strain data and the values of the elastic constants obtained from the coupon tests.

\section{(b) MAXIMUM LOAD}

One two-angle column of each group of three like two-angle columns was subjected to maximum-load test after the bolts had been replaced by rivets. Data to complete the stress-strain curves and data for stress-deflection curves were taken. 


\section{RESULTS}

\section{COUPONS}

The results of the tensile tests of the coupons are given in table 3 .

TABLE 3.-Results of tensile tests of coupons

\begin{tabular}{|c|c|c|c|c|c|c|}
\hline $\begin{array}{l}\text { Coupon } \\
\text { designation }\end{array}$ & Thickness & $\begin{array}{l}\text { Young's } \\
\text { modulus of } \\
\text { elasticity, } E\end{array}$ & $\begin{array}{l}\text { Poisson's } \\
\text { ratio, } \nu\end{array}$ & $\begin{array}{l}\text { Yield } \\
\text { point }\end{array}$ & $\begin{array}{l}\text { Tensile } \\
\text { strength }\end{array}$ & $\begin{array}{l}\text { Elongation } \\
\text { in } 8 \text { inches }\end{array}$ \\
\hline
\end{tabular}

PLATE COUPONS

\begin{tabular}{|c|c|c|c|c|c|c|}
\hline $\begin{array}{l}C 1 A(1-2) \\
C 1 A(3-4) \\
C 1 B(1-2) \\
C 1 B(3-4) \\
C 1 C(1-2) \\
C 1 C(3-4) \\
C 1 D(1-2) \\
C 1 D(3-4)\end{array}$ & $\begin{array}{r}\text { Inches } \\
0.377 \\
.377 \\
.377 \\
.378 \\
.385 \\
.382 \\
.382 \\
.379\end{array}$ & $\begin{array}{r}\text { Kips/in.2 } \\
29,600 \\
29.500 \\
29,500 \\
29,600 \\
29,600 \\
29,500 \\
29,400 \\
29,600\end{array}$ & $\begin{array}{r}0.285 \\
.280 \\
.281 \\
.280 \\
.274 \\
.278 \\
.281 \\
.276\end{array}$ & $\begin{array}{r}\text { Kips/in. }{ }^{2} \\
38.0 \\
39.4 \\
37.4 \\
38.1 \\
38.2 \\
37.5 \\
38.0 \\
38.6\end{array}$ & $\begin{array}{r}\text { Kips/in. }{ }^{2} \\
60.0 \\
60.1 \\
58.7 \\
58.7 \\
59.0 \\
58.4 \\
60.4 \\
60.5\end{array}$ & $\begin{array}{r}\text { Percent } \\
32.0 \\
32.8 \\
33.3 \\
30.6 \\
32.7 \\
34.1 \\
32.4 \\
32.7\end{array}$ \\
\hline
\end{tabular}

ANGLE COUPONS

\begin{tabular}{|c|c|c|c|c|c|c|}
\hline $\begin{array}{l}\text { C5A } 1(1-2) \\
C 5 A(3-4) \\
C 5 B(1-2) \\
C 5 B(3-4) \\
C 5 D(1-2) \\
C 5 D(3-4) \\
C 5 E(1-2) \\
C 5 E(3-4) \\
C 5 G(1-2) \\
C 5 B(3-4) \\
C 5 H(1-2) \\
C 5 H(3-4)\end{array}$ & $\begin{array}{l}0.510 \\
.506 \\
.506 \\
.510 \\
.500 \\
.507 \\
.508 \\
.508 \\
.509 \\
.503 \\
.512 \\
.506\end{array}$ & $\begin{array}{l}29,600 \\
30,000 \\
29,700 \\
29,700 \\
29,800 \\
29,700 \\
29,700 \\
29,600 \\
30,100 \\
29,800 \\
29,400 \\
29,400\end{array}$ & $\begin{array}{l}0.286 \\
.290 \\
.286 \\
.278 \\
.287 \\
.288 \\
.285 \\
.281 \\
.287 \\
.285 \\
.279 \\
.282\end{array}$ & $\begin{array}{l}36.3 \\
35.6 \\
36.0 \\
35.9 \\
37.0 \\
36.9 \\
37.5 \\
36.0 \\
37.2 \\
37.0 \\
38.6 \\
38.0\end{array}$ & $\begin{array}{l}59.0 \\
58.7 \\
59.5 \\
58.7 \\
63.7 \\
64.5 \\
59.5 \\
59.1 \\
64.3 \\
69.2 \\
65.7 \\
65.7\end{array}$ & $\begin{array}{l}33.5 \\
33.5 \\
31.3 \\
35.8 \\
33.1 \\
33.0 \\
31.3 \\
33.1 \\
32.4 \\
31.7 \\
29.0 \\
31.5\end{array}$ \\
\hline
\end{tabular}

The chemical composition of the coupon material is given in table 4.

TABLE 4.-Chemical composition of coupon material

\begin{tabular}{|c|c|c|c|c|}
\hline Composite sample & Carbon & Ma nganese & Phosphorus & Sulfur \\
\hline $\begin{array}{l}\text { Plates } C 1 \\
\text { Angles } C 5\end{array}$ & $\begin{array}{r}\text { Percent } \\
0.17 \\
.21\end{array}$ & $\begin{array}{r}\text { Percent } \\
0.56 \\
.56\end{array}$ & $\begin{array}{r}\text { Percent } \\
0.008 \\
.014\end{array}$ & $\begin{array}{r}\text { Percent } \\
0.03 \\
.03\end{array}$ \\
\hline
\end{tabular}

\section{COLUMNS}

(a) MODULUS OF COLUMN AND EFFECTIVE AREA OF PLATE

The moduli, $E^{\prime}$, of the columns, and the effective-area factors, $K$, with respect to shortening under compressive load, for the plates, are given in table $5 .^{2}$

\footnotetext{
${ }^{2}$ See pages 679 and 680 of reference [1].
} 
TABLE 5.-Moduli of columns, effective-area factors of plates, and maximum-stress ratios

\begin{tabular}{|c|c|c|c|c|c|c|c|}
\hline \multirow[b]{2}{*}{ Plate designation } & \multirow[b]{2}{*}{$\begin{array}{l}\text { Num- } \\
\text { ber of } \\
\text { angles }\end{array}$} & \multicolumn{3}{|c|}{ Based on gross area } & \multicolumn{3}{|c|}{ Based on net area } \\
\hline & & $\begin{array}{l}\text { Modu- } \\
\text { lus, } \\
E^{\prime}\end{array}$ & $\begin{array}{c}\text { Effec- } \\
\text { tive- } \\
\text { area } \\
\text { factor, } \\
K\end{array}$ & $\frac{\begin{array}{c}\text { Ratio, } \\
\text { Maximum stress }\end{array}}{P / A}$ & $\begin{array}{l}\text { Modu- } \\
\text { lus, } \\
E^{\prime}\end{array}$ & $\begin{array}{c}\text { Effec- } \\
\text { tive } \\
\text { area } \\
\text { factor, } \\
K\end{array}$ & $\begin{array}{c}\text { Ratio, } \\
\text { Maximum stress } \\
P / A\end{array}$ \\
\hline $\begin{array}{l}C 1 A(0-1) \\
C 1 A(2-3) \\
C 1 A(4-5\end{array}$ & $\begin{array}{l}2 \\
2 \\
2\end{array}$ & $\begin{array}{r}\text { Kips/in. } .^{2} \\
25,000 \\
25,100 \\
25,100\end{array}$ & $\begin{array}{r}0.63 \\
.64 \\
.64\end{array}$ & - & $\begin{array}{c}\text { Kips/in.2 } \\
30,400 \\
30,400 \\
30,600\end{array}$ & $\begin{array}{l}1.14 \\
1.14 \\
1.16\end{array}$ & - \\
\hline Avg & $\ldots$ & 25,100 & 0.61 & -2.77 & 30,500 & 1.15 & -2.28 \\
\hline $\begin{array}{l}C 1 A(0-1) \\
C 1 A(2-3) \\
C 1 A(4-5)\end{array}$ & $\begin{array}{l}4 \\
4 \\
4 \\
\end{array}$ & $\begin{array}{l}26,600 \\
26,800 \\
26,700 \\
\end{array}$ & $\begin{array}{r}0.62 \\
.65 \\
.65 \\
\end{array}$ & \begin{tabular}{ll}
$-\cdot-$ \\
\hdashline$-\cdot$ \\
$--\cdot$
\end{tabular} & $\begin{array}{l}29,900 \\
30,000 \\
30,000 \\
\end{array}$ & $\begin{array}{l}1.14 \\
1.17 \\
1.17 \\
\end{array}$ & - \\
\hline Avg & $\ldots$ & 26,700 & 0.64 & -2.50 & 30,000 & 1.16 & -2.22 \\
\hline $\begin{array}{l}C 1 B(0-1) \\
C 1 B(2-3) \\
C 1 B(4-5)\end{array}$ & $\begin{array}{l}2 \\
2 \\
2\end{array}$ & $\begin{array}{l}26,000 \\
26,000 \\
26,000\end{array}$ & $\begin{array}{l}0.71 \\
.71 \\
.71\end{array}$ & ( & & $\begin{array}{l}1.29 \\
1.29 \\
1.28\end{array}$ & n \\
\hline Avg & $\cdots$ & 26,000 & 0.71 & -3.24 & 31,500 & 1.29 & -2.67 \\
\hline $\begin{array}{l}C 1 B(0-1) \\
C 1 B(2-3) \\
C 1 B(4-5)\end{array}$ & $\begin{array}{l}4 \\
4 \\
4 \\
\end{array}$ & $\begin{array}{l}27,200 \\
27,200 \\
27,100 \\
\end{array}$ & $\begin{array}{l}0.71 \\
.72 \\
.70 \\
\end{array}$ & & $\begin{array}{l}30,500 \\
30,600 \\
30,500\end{array}$ & $\begin{array}{l}1.29 \\
1.29 \\
1.26 \\
\end{array}$ & \\
\hline Avg & $\ldots$ & 27,200 & 0.71 & -2.91 & 30,500 & 1.28 & -2.59 \\
\hline $\begin{array}{l}\text { C1C }(0-1) \\
\text { C1C } C(2-3) \\
\text { C1 } C(4-5)\end{array}$ & $\begin{array}{l}2 \\
2 \\
2\end{array}$ & $\begin{array}{l}26,700 \\
26,700 \\
26,700\end{array}$ & $\begin{array}{r}0.78 \\
.77 \\
.77 \\
\end{array}$ & & & $\begin{array}{l}1.40 \\
1.40 \\
1.40 \\
\end{array}$ & -.... \\
\hline Avg & $\ldots$ & 26,700 & 0.77 & -3.43 & 32,500 & 1.40 & -2.82 \\
\hline $\begin{array}{l}C 1 C(0-1) \\
C 1 C(2-3) \\
C 1 C(4-5)\end{array}$ & $\begin{array}{l}4 \\
4 \\
4 \\
\end{array}$ & $\begin{array}{l}27,600 \\
27,500 \\
27.600 \\
\end{array}$ & $\begin{array}{l}0.78 \\
.76 \\
.76\end{array}$ & & & $\begin{array}{l}1.40 \\
1.37 \\
1.38 \\
\end{array}$ & $-\cdots$ \\
\hline Avg & $\ldots$ & 27,600 & 0.77 & -3.06 & 31,000 & 1.38 & -2.72 \\
\hline $\begin{array}{l}C 1 D(0-1) \\
C 1 D(2-3) \\
C 1 D(4-5)\end{array}$ & $\begin{array}{l}2 \\
2 \\
2 \\
\end{array}$ & $\begin{array}{l}29,400 \\
29,300 \\
29,200 \\
\end{array}$ & & & $\begin{array}{l}29,400 \\
29,300 \\
29,200 \\
\end{array}$ & - & \\
\hline Avg & -........ & 29,300 & 1.00 & 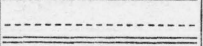 & 29,300 & 1.00 & \\
\hline $\begin{array}{l}C 1 D(0-1) \\
C 1 D(2-3) \\
C 1 D(4-5)\end{array}$ & $\begin{array}{l}4 \\
4 \\
4\end{array}$ & $\begin{array}{l}29,300 \\
29,300 \\
29,200 \\
\end{array}$ & & & $\begin{array}{l}29,300 \\
29,300 \\
29,200 \\
\end{array}$ & - & \\
\hline Avg. & & 29,300 & 1.00 & & 29,300 & 1.00 & \\
\hline
\end{tabular}

(b) STRESSES

(1) On the edge of the perforation.-The distribution of stress on the edge of the perforation is indicated in figures 2, 3, and 4. Each curve represents the average result for three like columns having the same perforation spacing.

The vertical axis of the graph in each figure is a development of one quadrant of the edge of the perforation.

In the stress ratios, $\sigma_{u, v} /\left(P / A_{n}\right), A_{n}$ is the net area of the column, and $\sigma_{u}$ and $\sigma_{v}$ are the maximum and the minimum principa? stresses, respectively. The stress ratios based on gross area, $\sigma_{u, v}(P / A)$, may be obtained by multiplying $\sigma_{u, v} /\left(P / A_{n}\right)$ by 1.22 for the two-angle and 1.12 for the four-angle columns.

The maximum stress ratios are given in table 5 . 


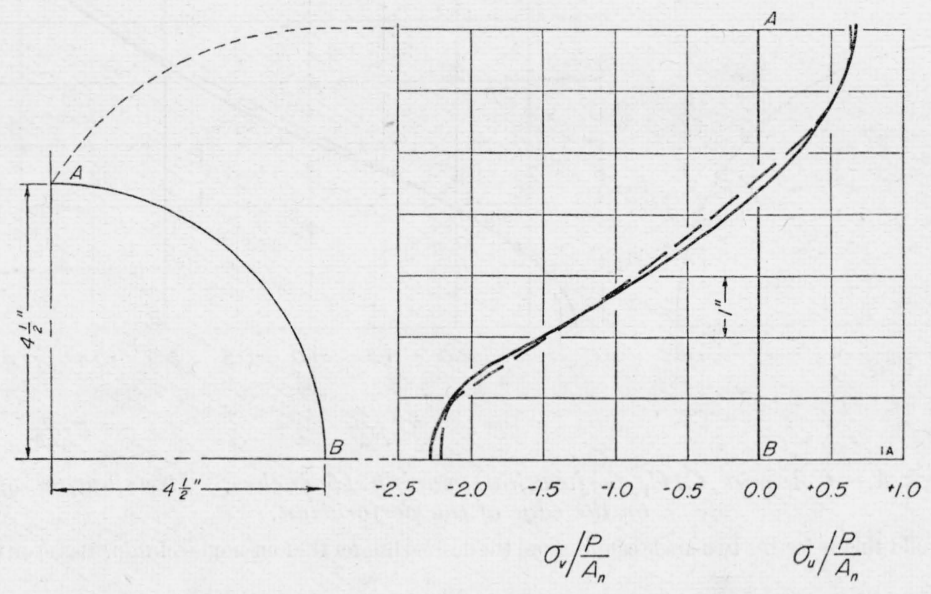

Figure 2.-Columns $C 1 A$, perforation spacing 21 inches. Distribution of stress on the edge of the perforation.

The solid line is for the two-angle column, and the dashed line for the four-angle column. Based on net area.

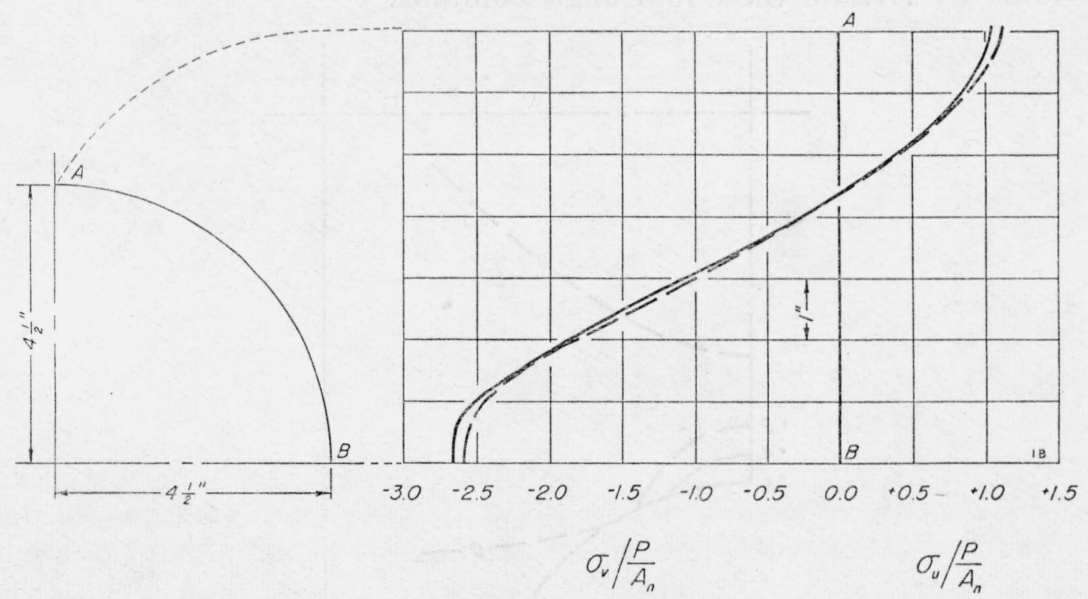

FIGURE 3.-Columns C1B, perforation spacing 33 inches. Distribution of stress on the edge of the perforation.

The solid line is for the two-angle column, and the dashed line for the four-angle column. Based on net area. 


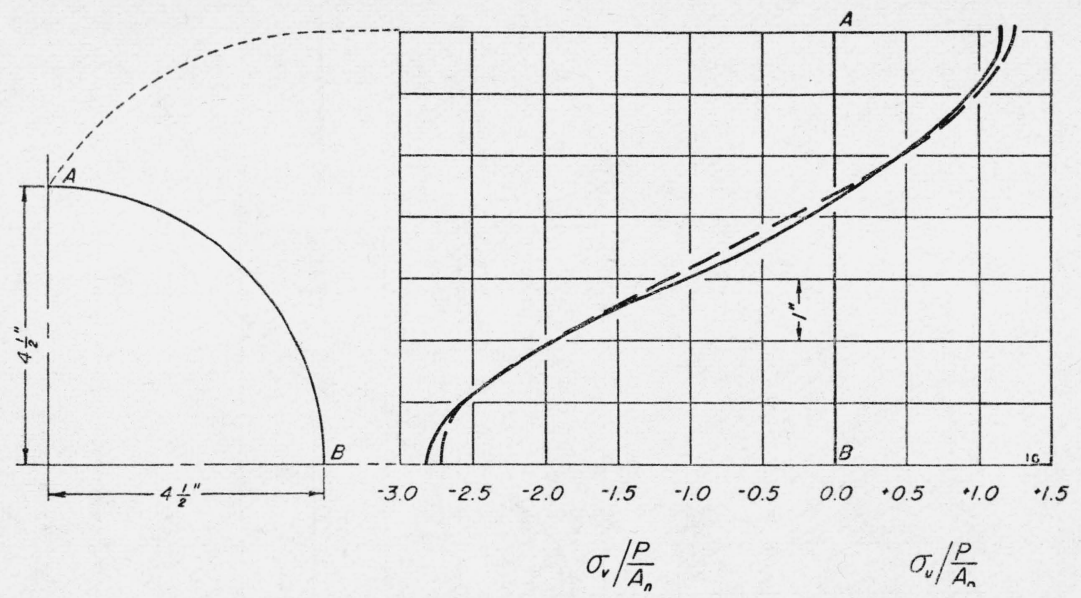

Figure 4.-Columns $C 1 C$, perforation spacing 45 inches. Distribution of stress on the edge of the perforation.

The solid line is for the two-angle column, and the dashed line for the four-angle column. Based on net area.

(2) On the surfaces of the plate.-The distributions of stress on the surfaces of the middle bay for the perforated plate columns having four angles are indicated in figures 5 to 16 , inclusive. The stress ratios shown in these figures are based on net area. The stress ratios based on gross area may be obtained by multiplying the given values by 1.12 for these four-angle columns.

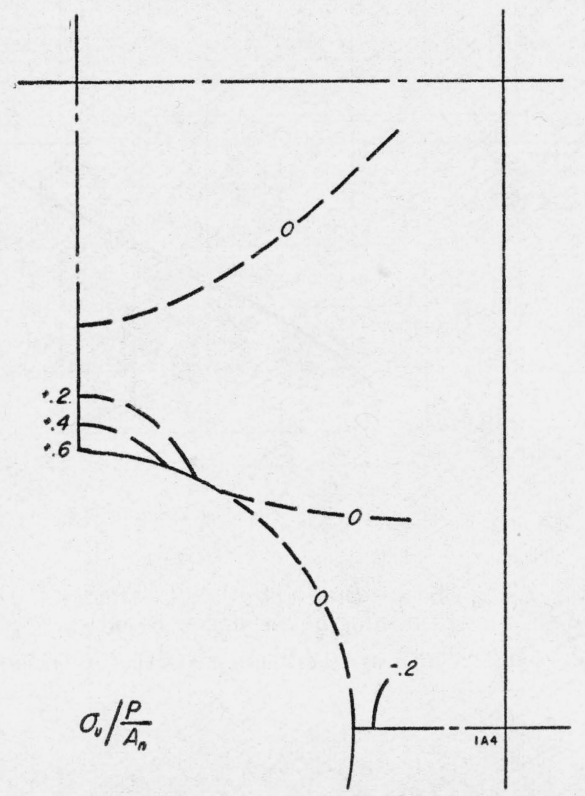

FIgURE 5.-Column C1A (2-8) (four angles), perforation spacing 21 inches. Isogram of maximum principal stress. 


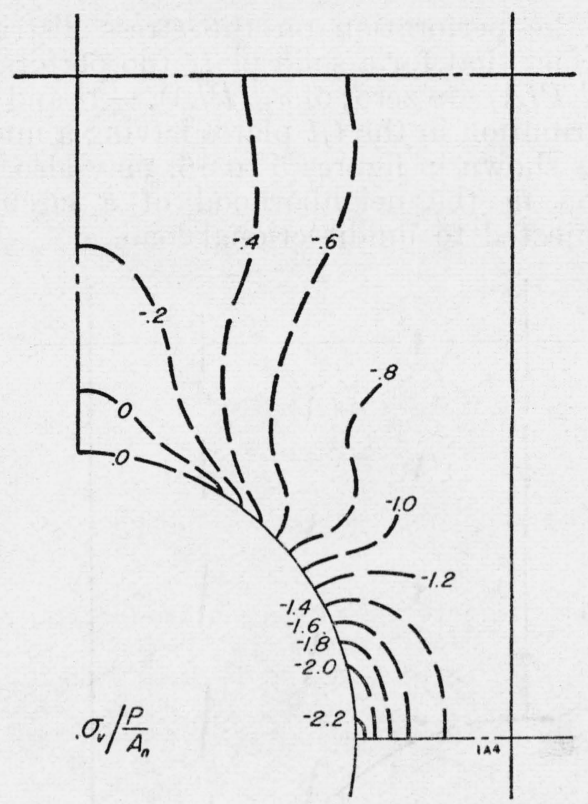

Figure 6.-Column C1A (2-3) (four angles), perforation spacing 21 inches. Isogram of minimum principal stress.

Based on net area.

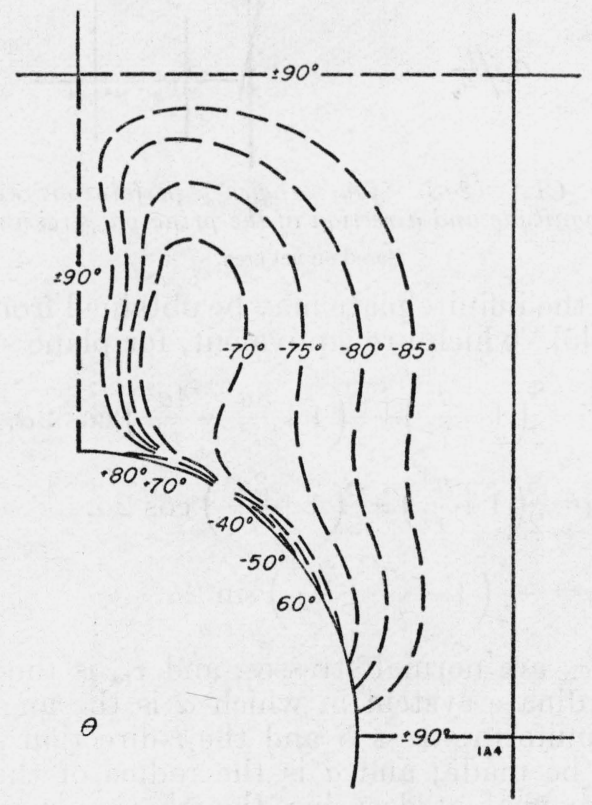

Figure 7.-Column C1A (2-3) (four angles), perforation spacing 21 inches. Isoclinics.

The angle $\theta$ is measured positive counterclockwise from the axis of the column to the direction of the maximum principal stress. 
The effect of the perforation on the stress distribution may be judged from the fact that for a solid plate (no perforation) the values everywhere of $\sigma_{u} /(P / A)$ are zero; of $\sigma_{v} /(P / A),-1$; and of $\theta, 90$ degrees.

The stress distribution in the $C 1$ plates having a number of circular holes in a row, as shown in figures 5 to 16 , may also be compared to stress distribution in the neighborhood of a circular hole in an infinite plate subjected to unidirectional load.

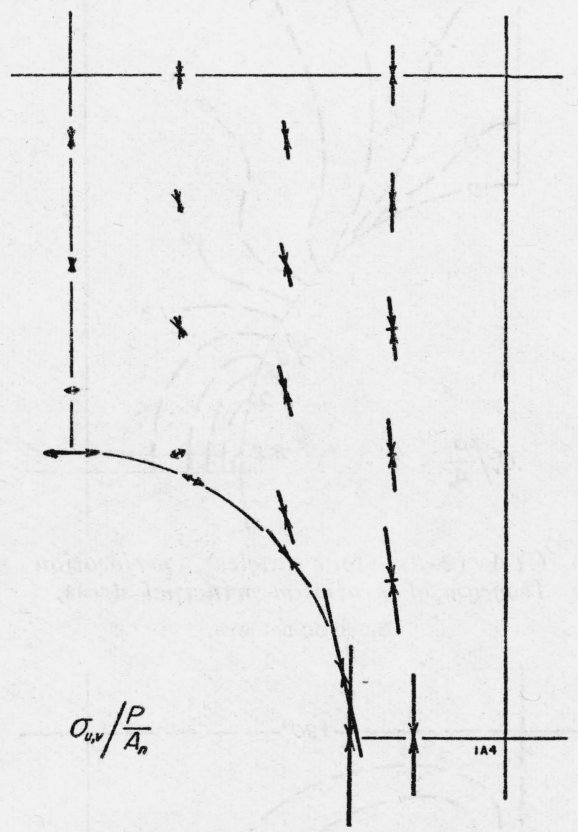

Figure 8.-Column C1A (2-3) (four angles), perforation spacing 21 inches. Magnitude and direction of the principal stresses.

Based on net area.

The stresses in the infinite plate may be obtained from the equations given by Kirsch [5], ${ }^{3}$ which are equivalent, for plane stress, to

$$
\begin{aligned}
\sigma_{r} & =\frac{S}{2}\left(1-\frac{a^{2}}{r^{2}}\right)+\frac{S}{2}\left(1+\frac{3 a^{4}}{r^{4}}-\frac{4 a^{2}}{r^{2}}\right) \cos 2 \alpha, \\
\sigma_{\alpha} & =\frac{S}{2}\left(1+\frac{a^{2}}{r^{2}}\right)-\frac{S}{2}\left(1+\frac{3 a^{4}}{r^{4}}\right) \cos 2 \alpha, \\
\tau_{r \alpha} & =-\frac{S}{2}\left(1-\frac{3 a^{4}}{r^{4}}+\frac{2 a^{2}}{r^{2}}\right) \sin 2 \alpha,
\end{aligned}
$$

in which $\sigma_{r}$ and $\sigma_{\alpha}$ are normal stresses, and $\tau_{r \alpha}$ is the shearing stress in the polar coordinate system in which $\alpha$ is the angle between the direction of the uniform stress $S$ and the $r$-direction for which computations are to be made; and $a$ is the radius of the circular hole. The stresses were evaluated, using the above equations and with $S=-1$, for a large number of points. From these values the magnitude and direction of the principal stresses for the points were found by the graphic method of O. Mohr, ${ }^{4}$ and are shown in figures 17 to 20 .

Or see page 77 of reference [6].

4 See page 17 of reference [6] 


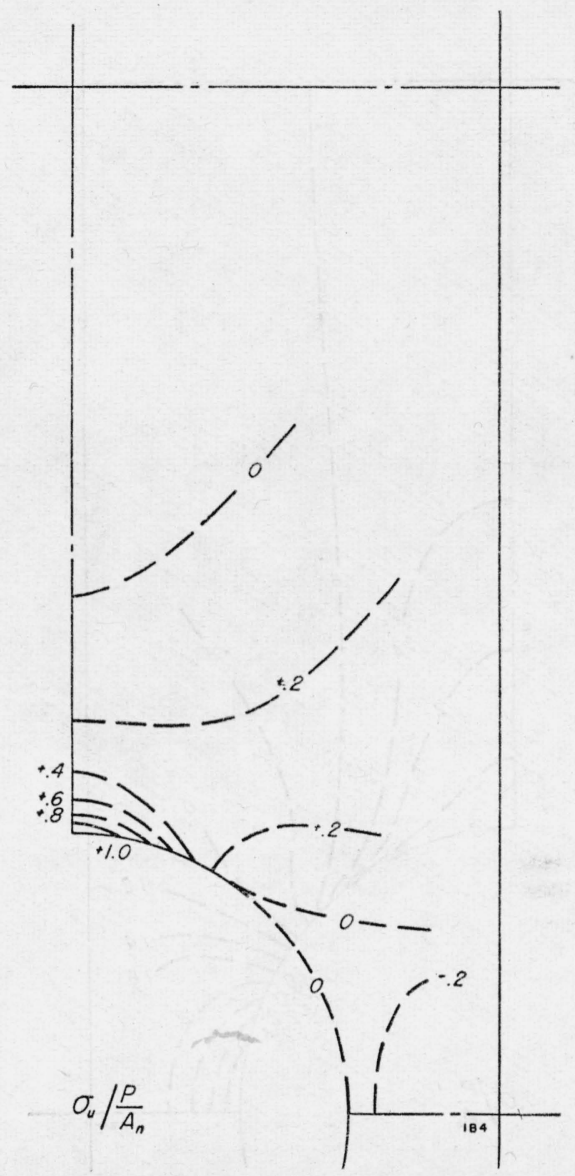

Figure 9.-Column C1B (2-3) (four angles), perforation spacing 33 inches. Isogram of maximum principal stress.

Based on net area. 
188 Journal of Research of the National Bureau of Standards

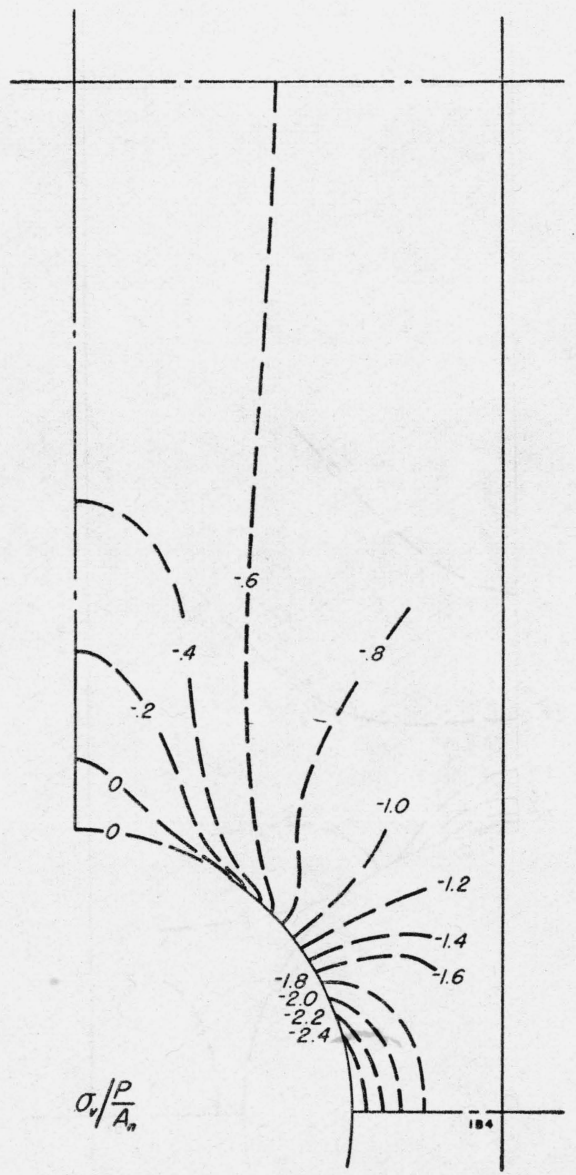

Figure 10.-Column C1B (2-3) (four angles), perforation spacing 33 inches. Isogram of minimum principal stress.

Based on net area. 


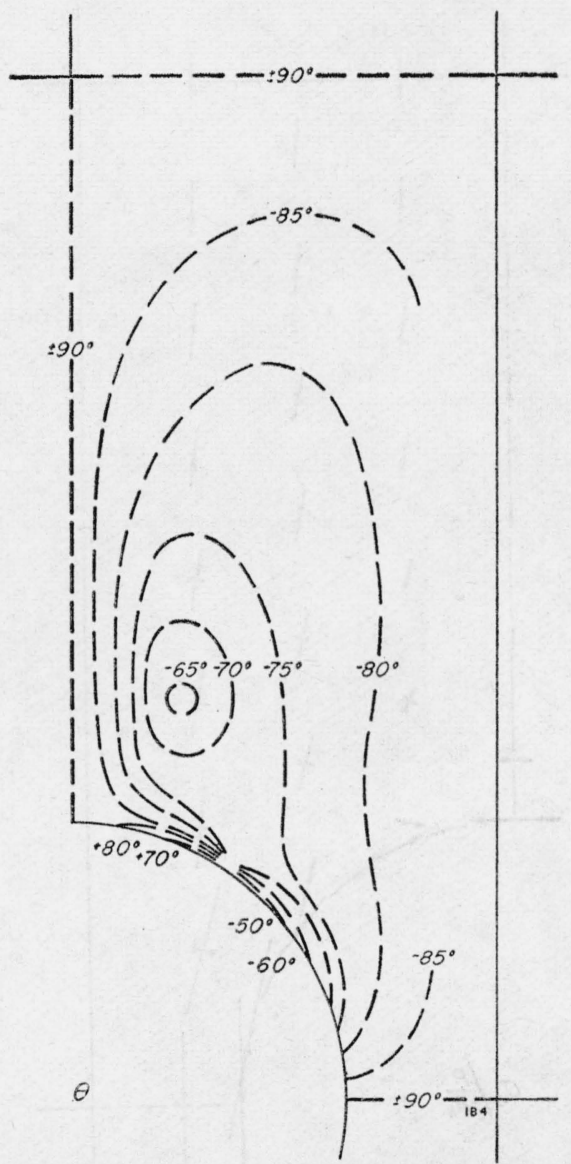

Figure 11.-Column C1B (2-3) (four angles), perforation spacing 33 inches. Isoclinics.

The angle $\theta$ is measured positive counterclockwise from the axis of the column to the direction of the maxi mum principal stress. 
190 Journal of Research of the National Bureau of Standards

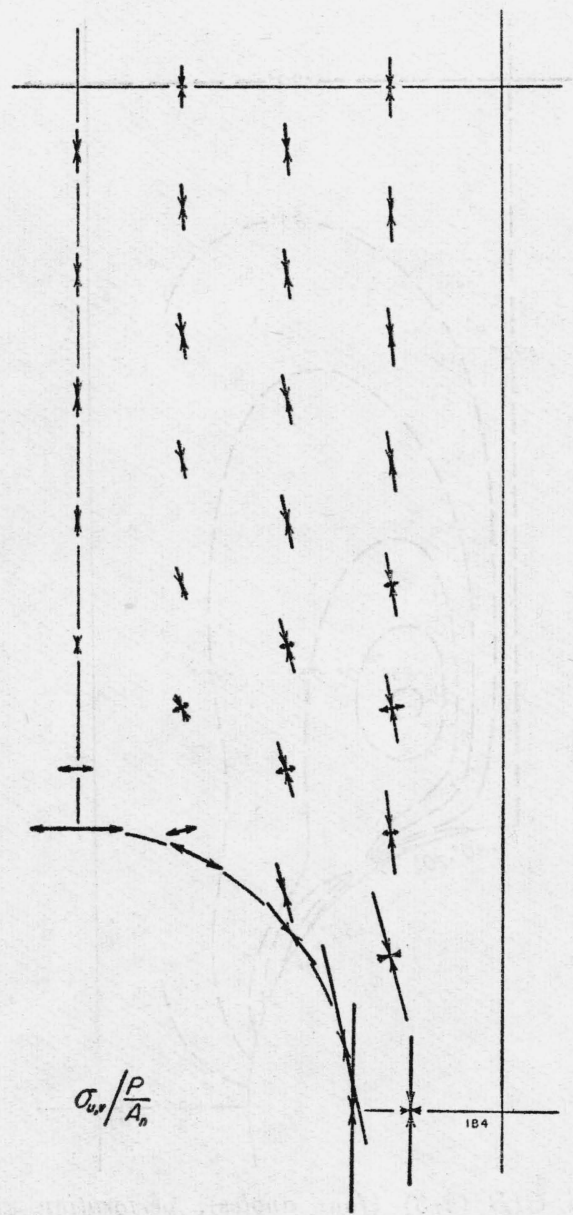

FIGURE 12.-Column C1B (2-S) (four angles), perforation spacing 33 inches. Magnitude and direction of the principal stresses.

Based on net area. 


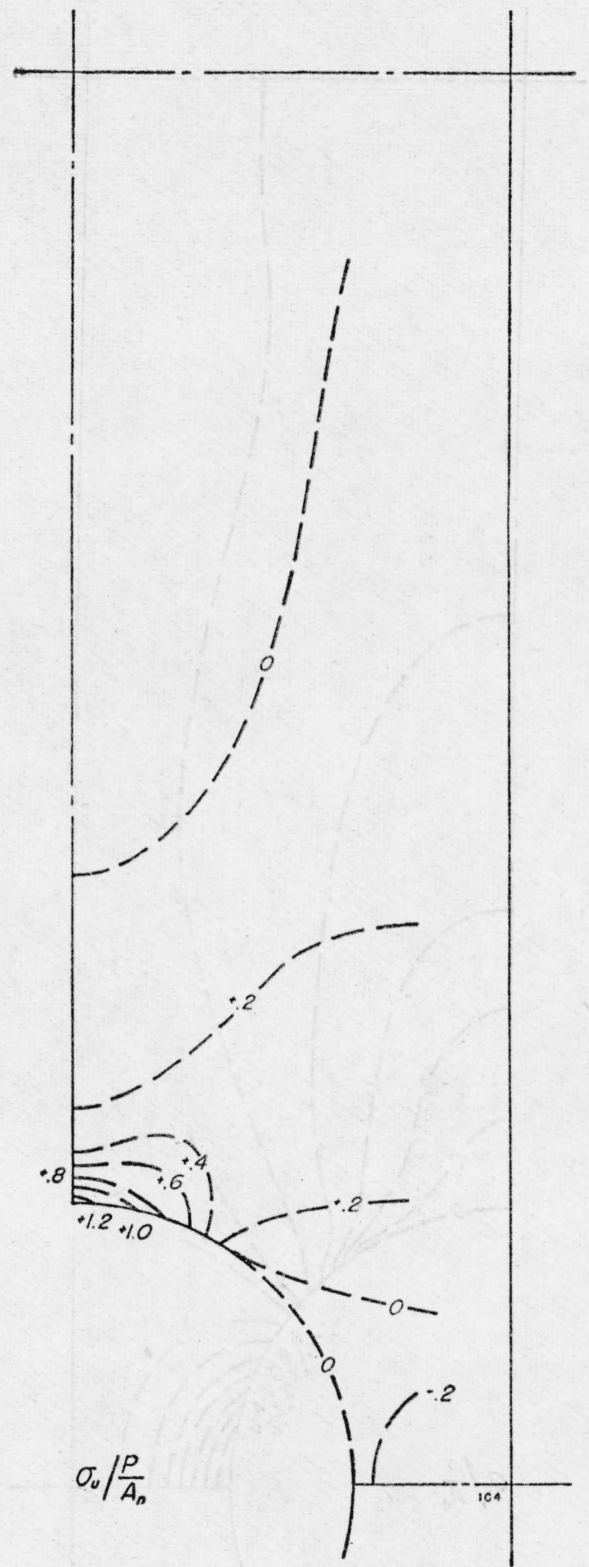

Figure 13.-Column C1C (2-3) (four angles), perforation spacing 45 inches. Isogram of maximum principal stress. Based on net area. 
192 Journal of Research of the National Bureau of Standards

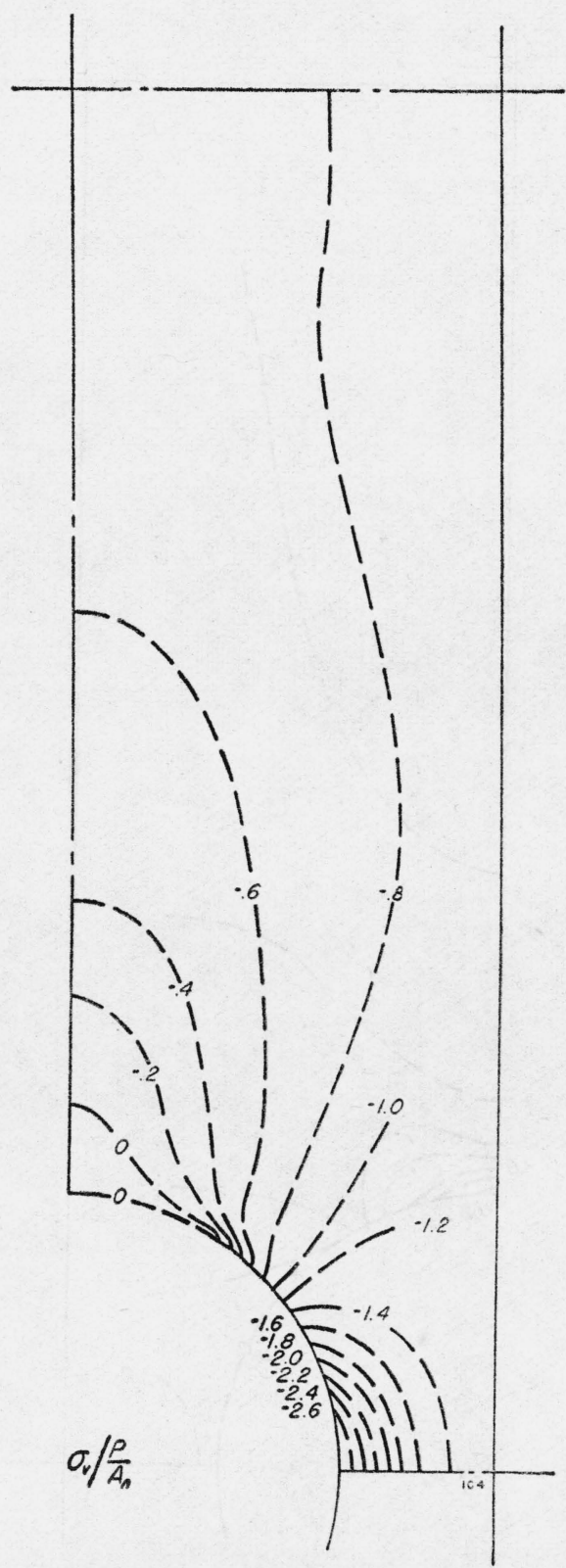

FIgURE 14.-Column C1C (2-3) (four angles), perforation spacing 45 inches. Isogram of minimum principal stress.

Based on net area. 


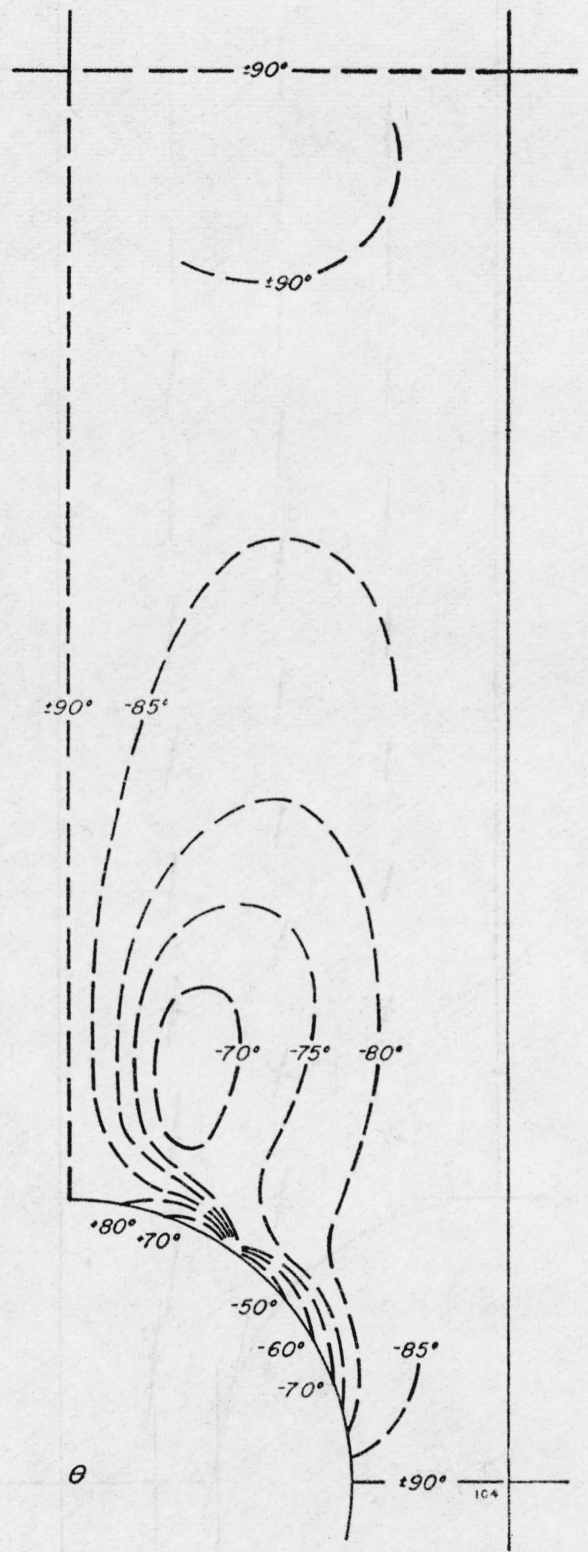

FIGURE 15.-Column C1C (2-8) (four angles), perforation spacing 45 inches. The angle $\theta$ is measured positive counterclockwise from the axis of the column to the direction of the maxmum principal stress. 


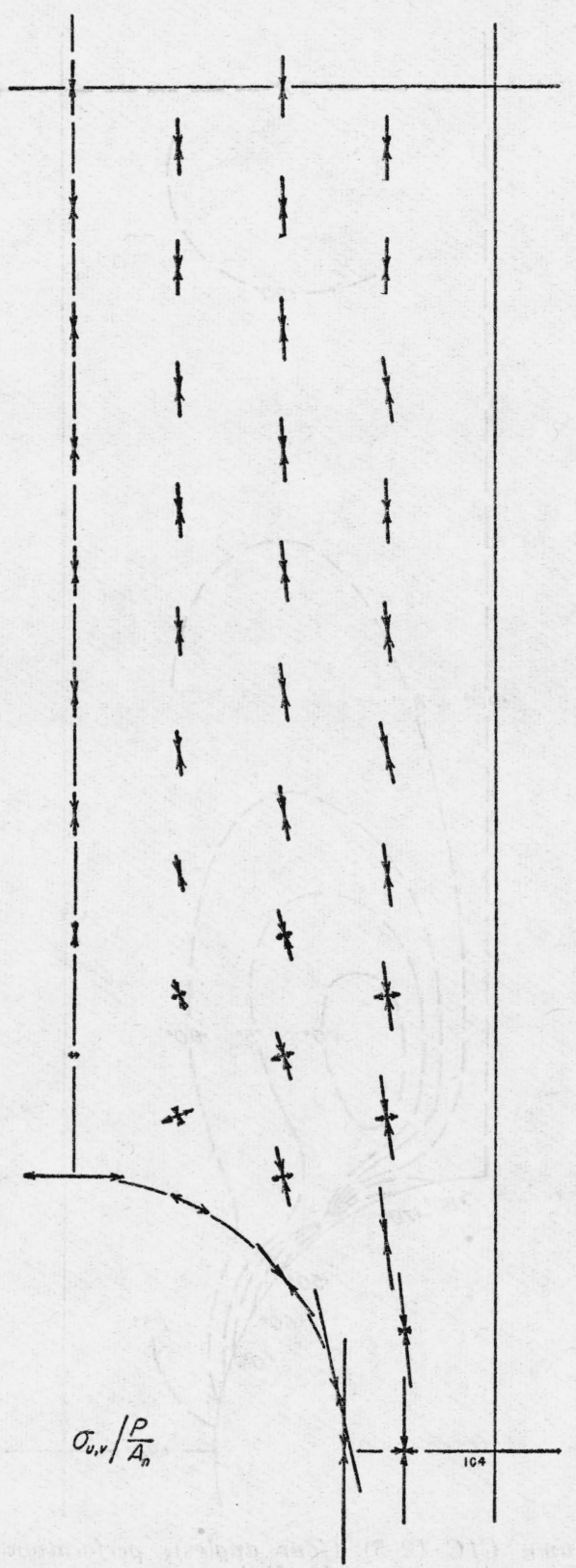

FIgURE 16.-Column C1C (2-3) (four angles), perforation spacing 45 inches. Magnitude and direction of the principal stresses. 


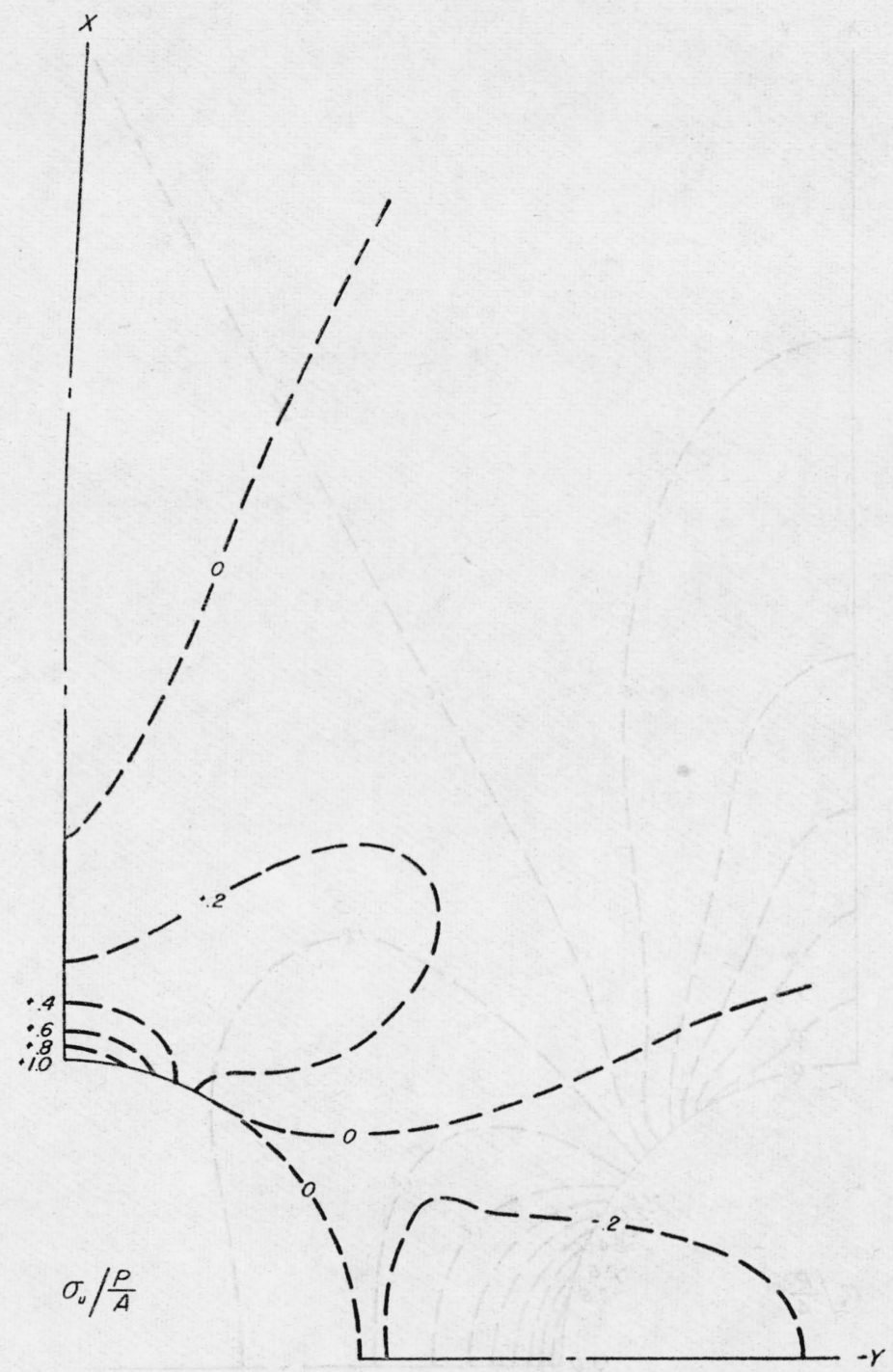

FIGURE 17.-Isogram of maximum principal stress in the neighborhood of a circular hole in an infinite plate subjected to a uniform compression in the $x$-direction. 


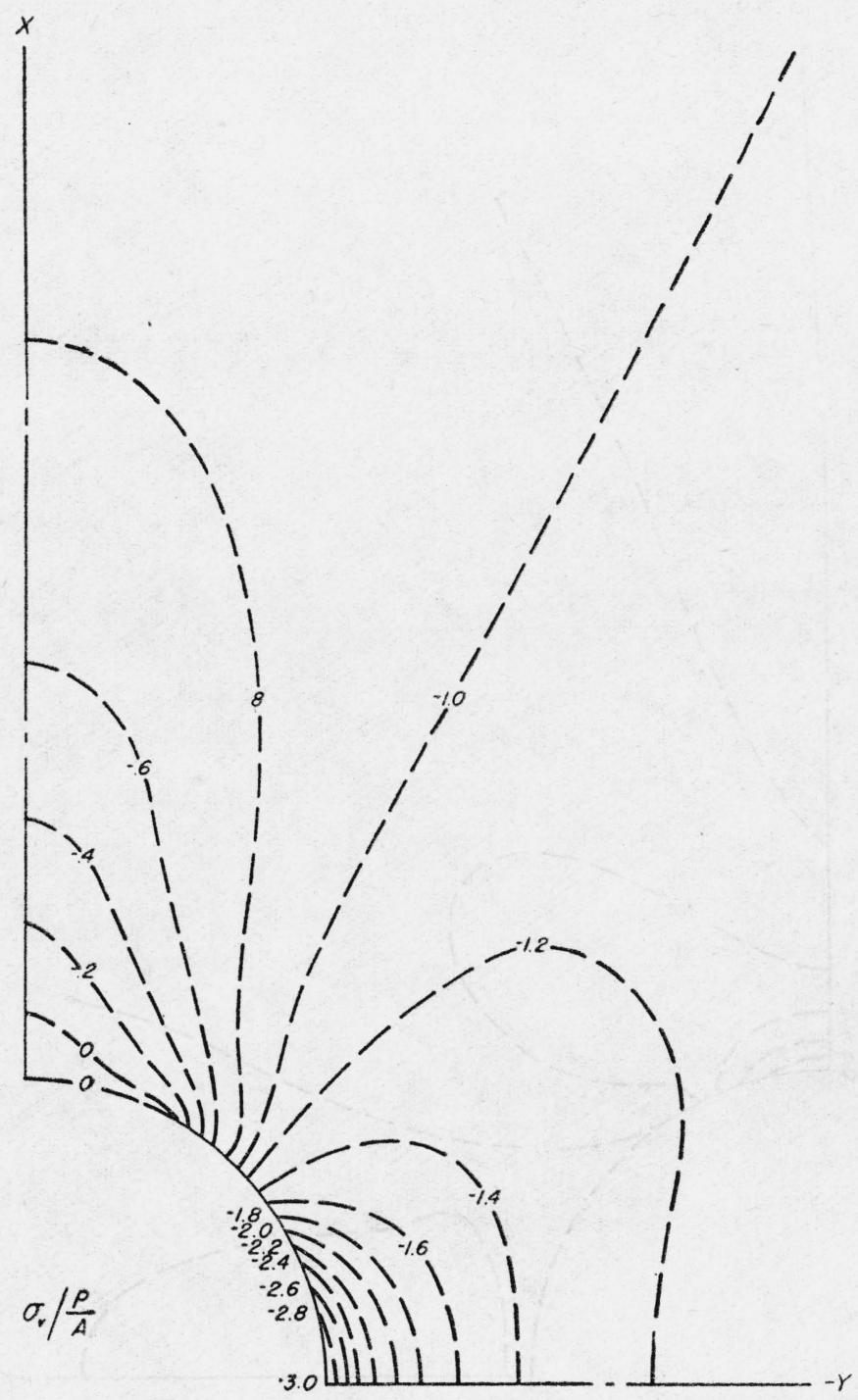

Figure 18.-Isogram of minimum principal stress in the neighborhood of a circular hole in an infinite plate subjected to a uniform compression in the $x$-direction. 


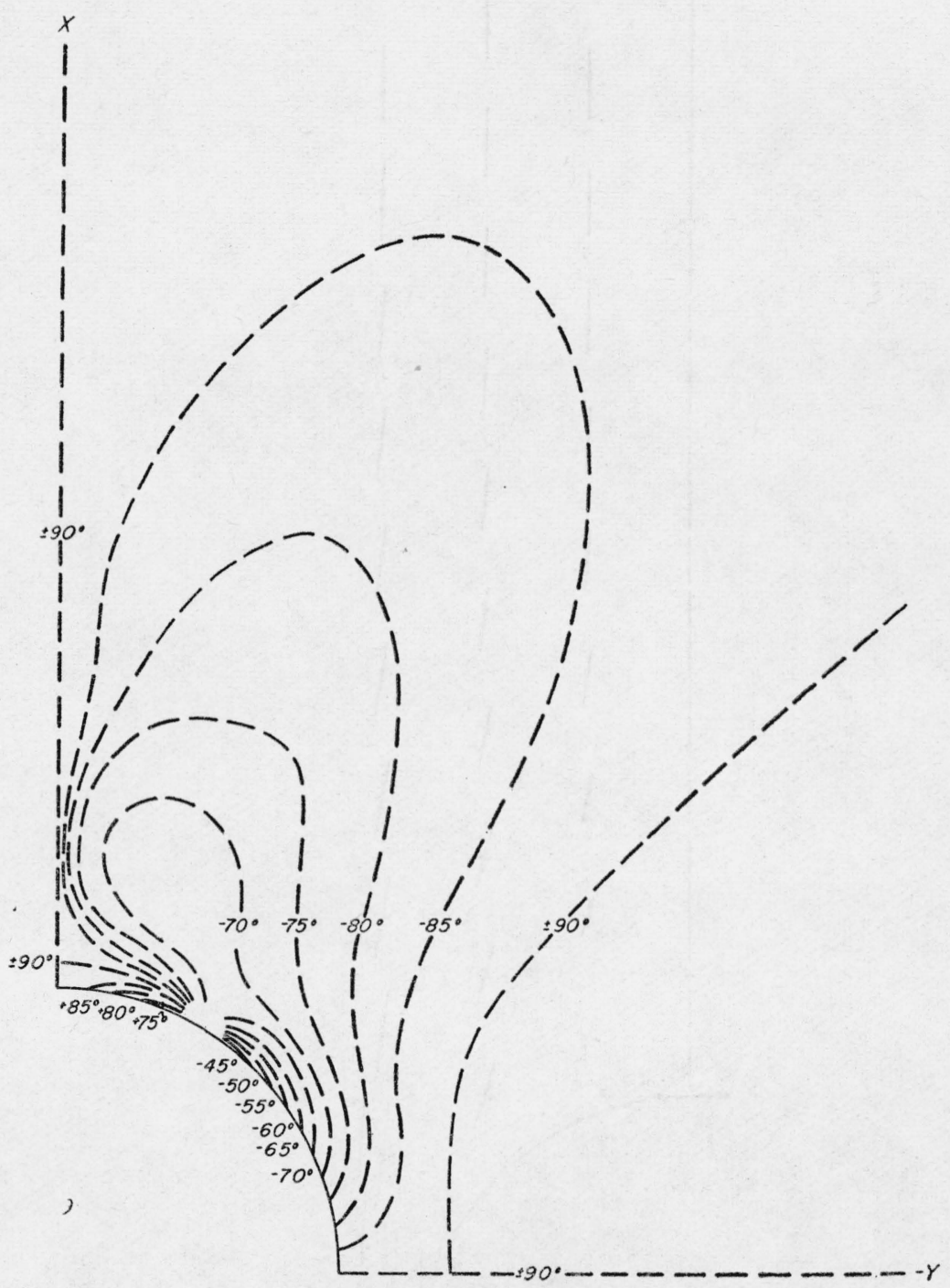

FIGURE 19.-Isoclinics in the neighborhood of a circular hole in an infinite plate subjected to a uniform compression in the $x$-direction.

The angle $\theta$ is measured positive counter clockwise from the $x$-direction to the direction of the maximum principal stress. 
198 Journal of Research of the National Bureau of Standards

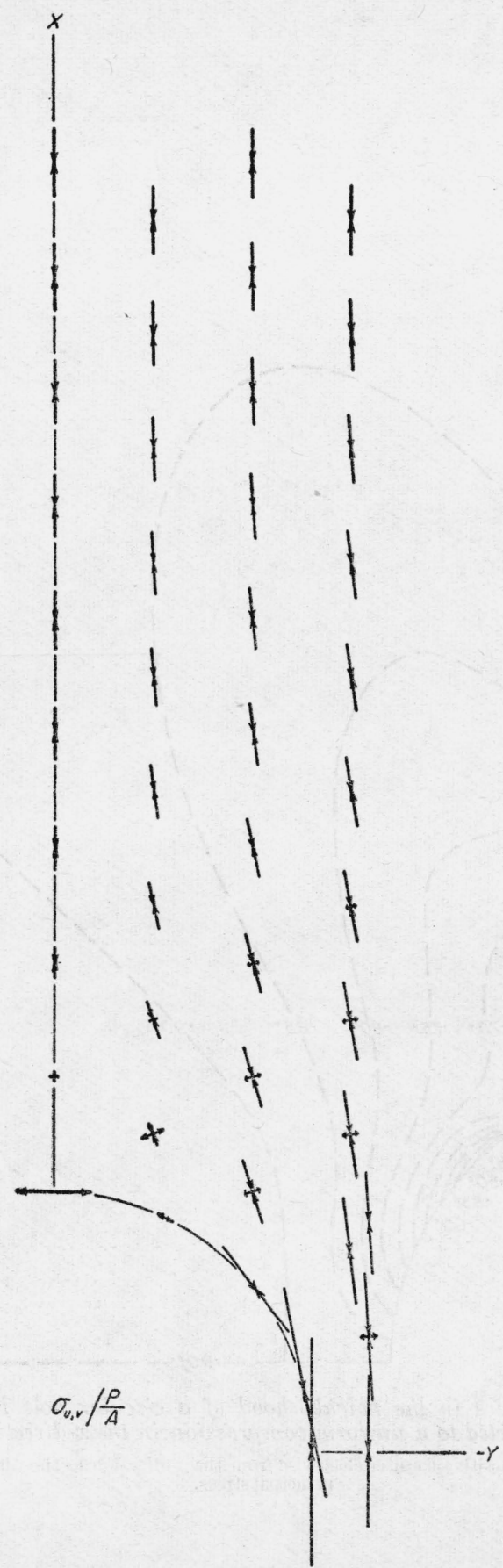

FIGURE 20.-Magnitude and direction of the principal stresses in the neighborhood of a circular hole in an infinite plate subjected to a uniform compression in the $x$-direction. 


\section{(c) MAXIMUM-LOAD TEST}

(1) Stress-strain graphs.-The stress-strain graphs for the columns, based on net areas, are shown in figure 21 .

The stresses on gross area may be obtained by multiplying the stresses on net area by 0.82 .

(2) Deflections.- The stress-lateral-deflection graphs for the columns, based on net area, are shown in figure 22 .

The stresses on gross area may be obtained by multiplying the stresses on net area by 0.82 .

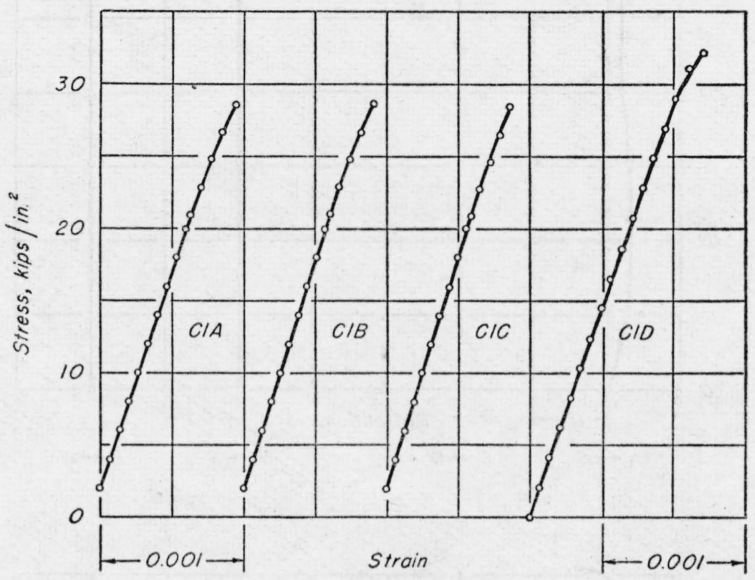

Figure 21.-Columns C1-(two angles). Stress-strain graphs.

Based on net area

(3) Maximum load and effective area of plate.-The maximum loads for the columns, the maximum average stress on the gross area and on the net area, and the effective-area factors of the plates with respect to compressive strength, $C$, are given in table $6 .^{5}$

The perforated-plate columns, $C 1 A, C 1 B$, and $C 1 C$ failed by primary buckling away from the plate side of the column, as would be expected from the consideration that, in the neighborhood of a per-

TABLE 6.-Maximum loads for columns and effective-area factors for plates

\begin{tabular}{|c|c|c|c|c|}
\hline Column designation & $C 1 A$ & $C 1 B$ & $C 1 C$ & $C 1 D$ \\
\hline Perforation spacing, $i n_{-}$ & \multirow{10}{*}{$\begin{array}{c}21 \\
11.53 \\
7.54 \\
4.20 \\
19.07 \\
15.73 \\
541 \\
28.4 \\
34.4\end{array}$} & \multirow{10}{*}{$\begin{array}{c}33 \\
11.58 \\
7.47 \\
4.14 \\
19.05 \\
15.71 \\
540 \\
28.3 \\
34.4\end{array}$} & \multirow{10}{*}{$\begin{array}{l}45 \\
11.57 \\
7.65 \\
4.21 \\
19.22 \\
15.78 \\
561 \\
29.2 \\
35.6\end{array}$} & \multirow{10}{*}{$\begin{array}{l}\text { (a) } \\
11.60 \\
7.62 \\
7.62 \\
19.22 \\
19.22 \\
624 \\
32.5 \\
32.5\end{array}$} \\
\hline Area of angles, $i n .^{2}$ & & & & \\
\hline Gross area of plate, in.2 & & & & \\
\hline Net area of plate, $i n .^{2}$ & & & & \\
\hline Total area, gross, in.2-- & & & & \\
\hline Total area, net, in. ${ }^{2}$ & & & & \\
\hline Maximum compressive load, Kips & & & & \\
\hline Compressive stress on gross area at failure, Kips/in.2 & & & & \\
\hline Compressive stress on net area at failure, Kips/in. ${ }^{2}$ & & & & \\
\hline $\begin{array}{l}\text { Effective-area factor of plate with respect to compressive } \\
\text { strength, } C \text { : }\end{array}$ & & & & \\
\hline Based on gross area & \multirow{3}{*}{$\begin{array}{l}0.68 \\
1.22\end{array}$} & \multirow{3}{*}{$\begin{array}{l}0.68 \\
1.22\end{array}$} & \multirow{3}{*}{$\begin{array}{l}0.74 \\
1.35\end{array}$} & 1.00 \\
\hline 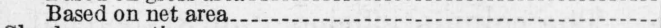 & & & & \\
\hline Slenderness ratio & & & & \\
\hline Column efficiency, Percent & & & & 87 \\
\hline
\end{tabular}

- No perforation.

- See page 685 of reference [1]. 
foration, the gravity axis of the column is displaced away from the plate side. Local buckling of the outstanding legs of the angles of the columns occurred near the ends of the column.

The unperforated-plate column $C 1 D$ started to deflect toward the plate side, as would be expected from the double-modulus theory, but
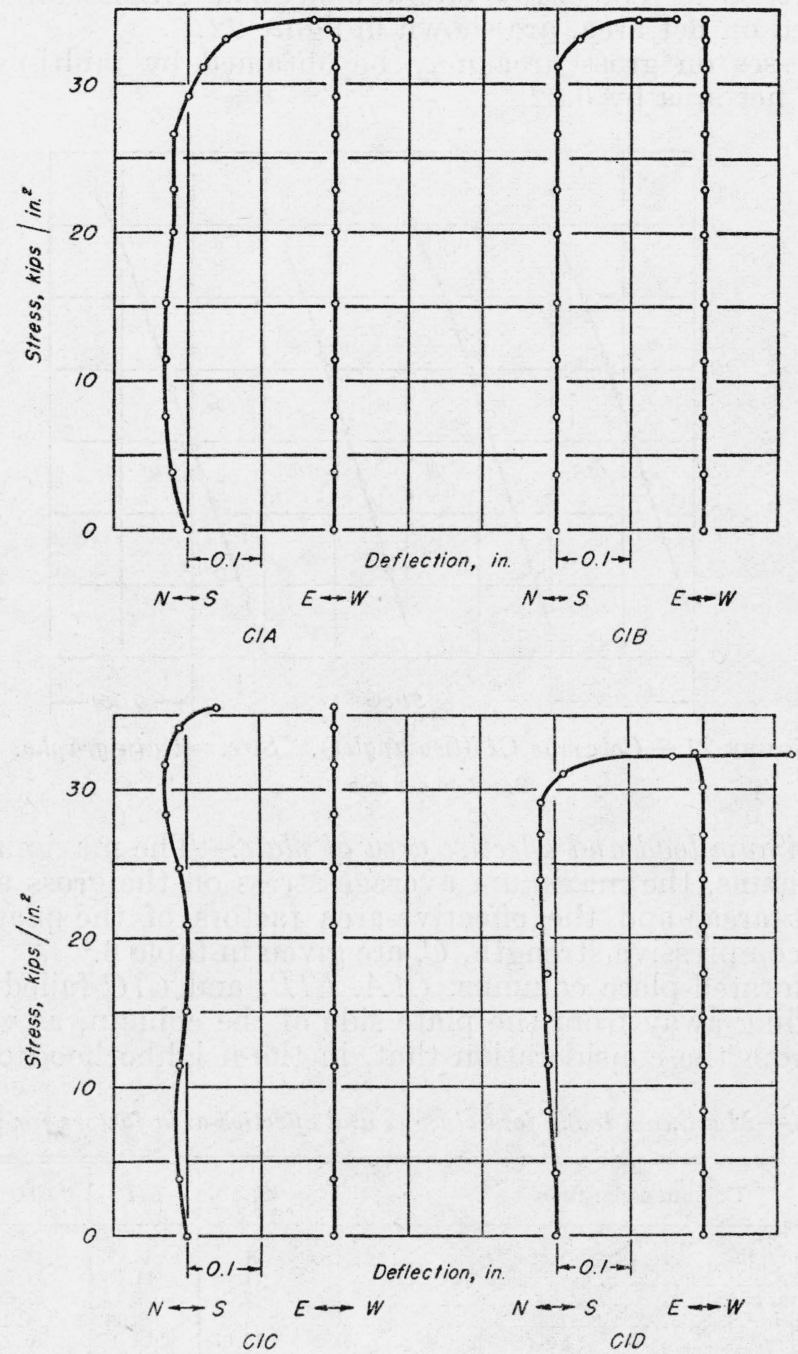

Figure 22.-Columns C1-(two angles). Stress-deflection graphs.

Based on net area. When the deflection is north, $N$, the bending stress is tensile on the plate side.

failed by secondary buckling of the plate at about one-third the height of the column from the base. The column efficiency of 87 percent, given in table 6 , is the ratio of the average stress at failure to the weighted average yield point of the material determined from the tensile tests of the coupons. This value of column efficiency is lower than would be expected for a column having a slenderness ratio of 


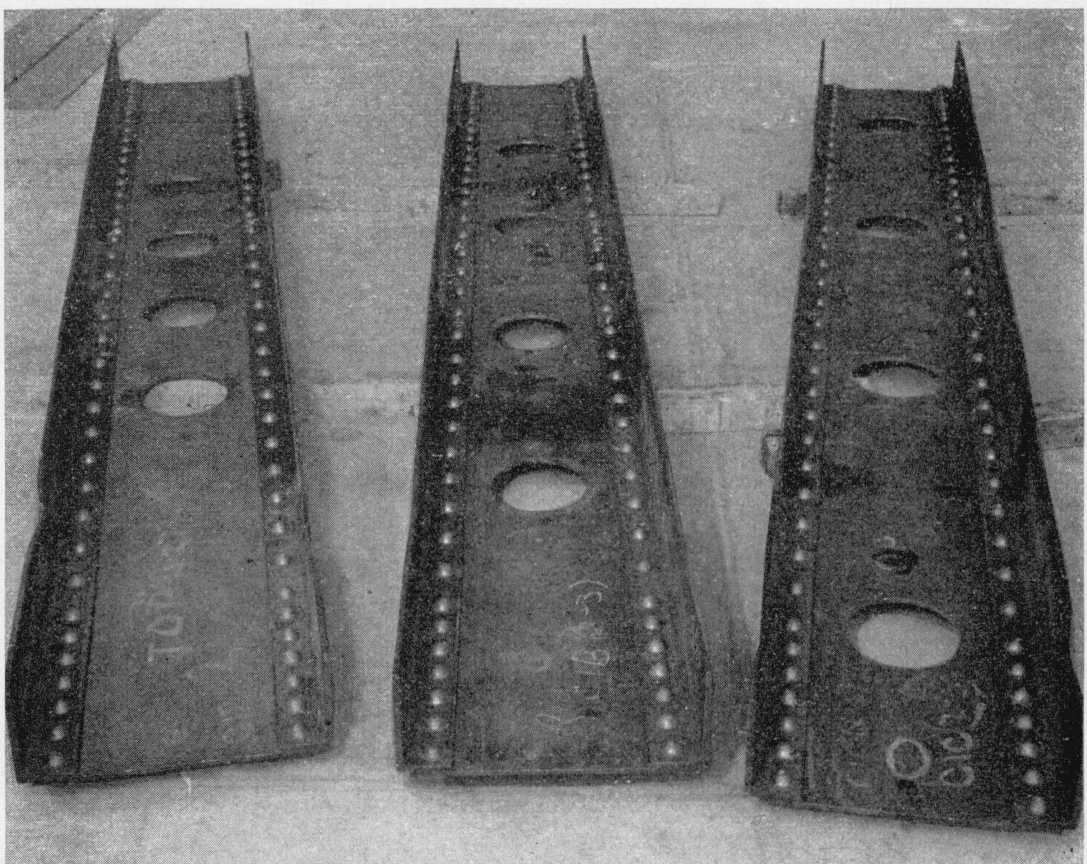

Figure 23.-Columns $C 1$ - (two angles) after maximum load tests.

From left to right the columns are $C 1 A, C 1 B$, and $C 1 C$. 
71 tested with flat ends. This low efficiency is due to the failure being at least partly by instability. The efficiency of column $C 1 D$ is intermediate to the efficiencies of the two previously tested unperforated-plate columns; column $C 2 D$ having a narrower cover plate and which failed largely as a whole, and column $C 4 D$ having a wider cover plate and which failed largely by elastic instability.

The effective-area factors, $C$, of the perforated plates with respect to compressive strength are of course greater than they would have been if the unperforated-plate column had failed at a higher stress owing to primary buckling. It may be noted that the compressive stresses at failure are somewhat greater for these $C 1$ columns having circular perforations than for the $C 3$ columns of the same plate width but having ovaloid perforations. ${ }^{6}$

Figure 23 shows the columns after test.

\section{SUMMARY}

\section{MODULUS}

The effectiveness of the perforated plates in resisting shortening under compressive load was determined by a comparison of the modulus of a column containing the perforated plate with that of a similar column containing an unperforated plate. It was found that from 64 to 77 percent of the gross cross-sectional area of the plate, depending on the perforation spacing, was effective in resisting shortening under compressive load. The effective-area factors for the perforated plates were not affected by variation in the number of angles with which they were tested.

\section{STRESS DISTRIBUTION}

The stress distribution was determined on the edge of the perforation in the middle bay length of each perforated-plate column and on the middle bay of one of each group of three like columns having four angles. In every case the maximum stress was compressive and occurred on the edge of the perforation. The value of the maximum stress increased with increase of perforation spacing. For columns with the same perforation spacing, the maximum stress was higher for the two-angle than for the four-angle column for the same average stress on the gross area or on the net area.

The maximum stress varied from 2.5 to 3.4 times the average stress on the gross area, or 2.2 to 2.8 times the average stress on the net area. These values of stress concentrations for these circular perforations were greater than for any of the columns having ovaloid perforations.

\section{STRENGTH}

The effectiveness of the perforated plates with respect to strength was about the same as with respect to resistance to shortening and was little affected by change of perforation spacing. The compressive stresses at failure for the columns having circular perforations were somewhat greater than for columns having the same plate width but having ovaloid perforations.

\footnotetext{
6 See page 36 of reference [4].
} 


\section{Journal of Research of the National Bureau of Standards}

\section{REFERENCES}

[1] Ambrose H. Stang and Martin Greenspan, Perforated cover plates for steel columns: Program and test methods. J. Research NBS 28, 669 (1942) RP1473.

[2] Ambrose H. Stang and Martin Greenspan, Perforated cover plates for steel columns: Compressive Properties of plates having ovaloid perforations and a width-to-thickness ratio of 40. J. Research NBS 28, 687 (1942) RP1474.

[3] Ambrose H. Stang and Martin Greenspan, Perforated cover plates for steel columns: Compressive properties of plates having ovaloid perforations and a width-to-thickness ratio of 68. J. Research NBS 29, 279 (1942) RP1501.

[4] Ambrose H. Stang and Martin Greenspan, Perforated cover plates for steel columns: Compressive properties of plates having ovaloid perforations and a width-to-thickness ratio of 53. J. Research NBS 30, 15 (1943) RP1514.

[5] G. Kirsch, Die Theorie der Elastizität und die Bedürfnisse der Festigkeitslehre. Z. Ver. deut. Ing. 42, 797 (1898).

[6] S. Timoshenko, Theory of Elasticity (McGraw-Hill, Book Co. Inc., New York, N. Y. 1934.)

Washington, December 29, 1942. 